\title{
The Rules at the Youth Educational Centre - from the Perspective of Caretakers and Adolescents
}

\author{
dr Marzanna Farnicka, \\ Wydział Nauk Społecznych Uniwersytetu Zielonogórskiego, \\ Al. Wojska Polskiego 69, 65-762 Zielona Góra \\ mgr Astina Koch \\ Wydział Nauk Społecznych Uniwersytetu Zielonogórskiego, \\ Al. Wojska Polskiego 69, 65-762 Zielona Góra
}

\begin{abstract}
Staying in a Youth Educational Centre meets the isolation criteria. Therefore, it may deprive adolescents of important needs and trigger specific group processes characteristic of subcultures. This article concentrates on the creation of norms and rules in the group of teenagers placed in social rehabilitation institutions. The research question referred to the similarities and differences in the perception of norms, rules and hierarchy in Youth Educational Centres by their employees and the minors.The Focus Group Interview and the method of competent judges were used as the research method for the caretakers, and the survey was used when researching the adolescents. Interviews were conducted with the caretakers and the adolescents. The study group consisted of 32 adolescents and 7 employees. It was conducted at Youth Educational Centre in Lower Silesia as a pilot study. The research results reveal a similar perception of rules in the centre by the caretakers and adolescents. Despite the mixed research methodology and the changing environment of modern adolescents (globalization and functioning in cyberspace), the research confirmed the earlier results in terms of the content of the rules functioning in the centre. Moreover, the caretakers listed a richer range of the determinants of the observed behaviour and the process of rule formation. The adolescents focused mainly on situational factors and used masking strategies.
\end{abstract}

Keywords: adolescence, prison rehabilitation, subculture, rules

DOI: $10.7176 /$ RHSS/11-11-02

Publication date:June $30^{\text {th }} 2021$

\section{Introduction}

Youth Educational Center (YEC) as an educational and isolation institution (Regulation of the Ministry of National Education, 2011) aims to eliminate the causes and symptoms of social maladjustment (Jaworska, 2009; Supreme Chamber of Control, NIK 2018). Therefore, staying at the centre is of deprivation nature (Posłuszny, 2017). The numerous literature indicates that in conditions of isolation (in the so-called total institutions) a group process becomes important as it makes it possible to satisfy the sense of security and belonging (Ciosek, PastwaWojciechowska, 2001). The social behaviour, norms and values which are created are important from the point of view of a closed group that can be treated as a subculture of a given centre. Research indicates that the phenomenon of subculture formation applies to both "total" (prison) and educational centres (Sarzała, 2013).

There are several definitions of subculture in closed institutions. The most popular and researched ones concern the prison subculture (Dolata, 2011), also known as the "informal social organization of the institution" (Krukowski, 1984) or the "second life subculture" (Drwal, 1981; Moczydłowski, 1998). In this approach, "subculture" means "all norms, values and patterns that determine the behaviour of all people participating in social processes that are created within the prison" (Dolata, 2011). In the prison subculture, three core values that set goals and strengthen the cohesion of the group are distinguished. They include: the negation of official laws and the fight against those who represent and enforce them; group solidarity, and personal dignity, the socalled "secret honour" (Ciosek, Pastwa-Wojciechowska, 2001 p. 235; Krause, Przybyliński, 2012; Szaszkiewicz, 1997, pp. 45-60, Sarzała, 2013).

The literature also mentions two models of the formation of the subculture in prison isolation (Skręt, 2004). One model, called the deprivation model, assumes that depriving an individual of freedom causes a significant limitation in meeting his/her essential needs. The model assumes that functioning in this community is based on mutual loyalty and solidarity, and allows individuals to significantly alleviate the discomfort associated with isolation. The other model, the so-called importation or transmission model, assumes that informal life is connected with a system of values and norms of behaviour that is superior to other systems. The two models fit into the broader approach of Erving Goffman, who points out that the social life of individuals can be treated as a kind of game whose task is to gain the approval of the group and take the right place in it (Goffman, 1975; 1981). 


\section{Purpose of research}

In the study, it has been assumed that in educational institutions it is important to know the coherence or parallelism of the perception of norms and principles between the youth and their caretakers. High consistency would create a basis for considering the creation of standards in these institutions according to the importation model. In order to analyze the process of creating rules among the youth and their caretakers, a developmental approach was taken into account. In this perspective, which is repeatedly discussed in the literature, the antisocial development is often diagnosed among young people staying at the YEC. Based on numerous studies conducted by educators (Malorny, 2008), sociologists (Chomczyński, 2015) and psychologists (Cicchetti, Rogosch, 1996), it should be noted that the determinants of antisocial development are complex and have a biopsychosocial character. It is worth emphasizing that, apart from temperamental, personality and situational conditions, "maladjusted" youth often comes from environments that have specific norms and rules (Thornberry, Lizotte, Krohn, Farnworth, \& Jang, 1994). Their living environments do not satisfy their important mental needs (Ostaszewski, 2008; Rode, 2010).

The literature also indicates that adolescents staying at YECs "show lack of involvement in social activities, are passive, and are often characterized by excessive hedonism and consumerism. They tend not to trust others, they are withdrawn, they escape from reality. They are characterised by extremism, violence and even terrorism. The reaction of individuals may be the result of overload or deprivation of stimuli" (Wilczyńska, 2013, p. 17), lack of a sense of security or faith in adult support (Szafrańska, 2016), "manifestation of various behavioural disorders, low level of motivation, school negativity, external sense of control, egocentrism "(Dobijański, 2019, p. 309). Based on the meta-analysis of numerous studies, Mariusz Granosik, Anita Gulczyńska and Renata Szczepanik (2014) indicate that for $48 \%$ of caretakers respecting rules is a very important component of educational success.

In the presented study, attempts were made to recognize the differences and similarities between the ways the caretakers and the youth describe he formation of norms and rules. The study was planned to answer the following questions: What are the rules of functioning in the facility and how are they shaped? Is it possible to identify the genesis of norm making as a deprivation or importation model? Is it possible to recognize the rules which are to serve the main values of the prison subculture (negation of official laws and the fight against people who represent and enforce them; group solidarity and personal dignity)?

\section{Research method}

The research methods come from the interpretative trend. This allows for the closest approach to the studied phenomena and processes (Farnicka 2019). The construction of the research situation was based on the categories distinguished by Piotr Chomczyński (2015). When analyzing the obtained material, efforts were made to go beyond the limitations related to the adopted research model (loss of objectivity, high contextual nature and relationality), using the method of competent judges. The validity of the judges' opinions is a method of testing criteria validity. (Farnicka 2019; Gorbaniuk, 2016, pp. 1-20).

The study group consisted of 7 caretakers, including 5 males $(80 \%)$ and 2 females $(20 \%)$ and 32 adolescents aged between 14 and 17 (mean age $\mathrm{M}=15.5 ; 15$ respondents (46\%) were aged 14-15, and 17 (52\%) were 16-17) in one of the Youth Educational Centres in Lower Silesia. This was a pilot study, so the centre was selected after receiving a permission from the head of the facility.

A focus group interview was used as a research method for caretakers and a survey with open and closed questions was used among the juveniles.

In the focus group interview the caretakers were asked the following questions: What are the reasons for the observed behaviour among the adolescents? What are their attitudes towards the rules in the centre? What is important for the adolescents staying in the centre? How are the rules of functioning in the facility shaped? What are the main rules for the adolescents in this centre? This method makes it possible to know the opinions of the caretakers, exchange information and their points of view, and draw conclusions.

The statements and categories provided by the caretakers were assessed by appointed competent judges (researchers: one specializing in psychology and one specializing in pedagogy, and four university students: two students of pedagogy and 2 students of psychology). The values of the coefficients proving the varying degree of compliance of the compared opinions of the judges range from 0 to 1 , where 0 means compliance at the case level, and 1 means that the judges' decisions are identical. The training of the judges and the calculation of their compliance was carried out in accordance with the guidelines of George Ferguson and Yoshio Takane (2004) and Oleg Gorbaniuk (2016, pp. 1-20).

A questionnaire was used to research the youth. The questions were developed on the basis of research conducted in correctional facilities and shelters for minors (Chomczyński, 2015).

\section{Research results}

The research results are presented in two groups. One includes the material collected among the caretakers, and 
the other contains the material gathered among the adolescents.

The results of the research conducted among the caretakers

The caretakers' statements are attached in the appendix and the results are presented in Table 1. The table also contains the results on the relevance of the categories determined by the competent judges.

Table 1. Relevance of the presented categories based on indications of competent judges

\begin{tabular}{|c|c|c|}
\hline Question & Categories and caretakers' answers & $\begin{array}{ll}\text { Compliance } & \text { of } \\
\text { competent judges }\end{array}$ \\
\hline \multirow[t]{2}{*}{$\begin{array}{l}\text { What are the reasons for adolescents' } \\
\text { behaviour? }\end{array}$} & $\begin{array}{l}\text { Family conditions, lack of warmth and } \\
\text { closeness }\end{array}$ & 0.9 \\
\hline & $\begin{array}{llll}\begin{array}{l}\text { adaptation } \\
\text { adolescence }\end{array} & \text { problems } & \text { related } & \text { to } \\
\end{array}$ & 0.9 \\
\hline \multirow[t]{3}{*}{$\begin{array}{l}\text { What are the adolescents' attitudes towards } \\
\text { the rules in the centre? }\end{array}$} & $\begin{array}{l}\text { they follow the existing norms and } \\
\text { accept them from the caretakers }\end{array}$ & 0.7 \\
\hline & It depends on adaptation process & 0.9 \\
\hline & It depends on peers & 0.8 \\
\hline \multirow{5}{*}{$\begin{array}{l}\text { What is important for the adolescents staying } \\
\text { in the centre? }\end{array}$} & Feeling important & 0.7 \\
\hline & Feeling successful & 0.9 \\
\hline & the need to belong to a group & 0.9 \\
\hline & sense of security & 0.7 \\
\hline & the need for physical activity & 1 \\
\hline \multirow{4}{*}{$\begin{array}{l}\text { How are the rules of functioning in the } \\
\text { facility shaped and what are they like? }\end{array}$} & By caretakers & 0.7 \\
\hline & By adolescents & 0.8 \\
\hline & They depend on the length of stay & 0.7 \\
\hline & As a rebellion and fight & 0.6 \\
\hline
\end{tabular}

Source: author's own work

The results of the research conducted among the adolescents

The results of the research in the group of adolescents are presented in Table 2. It should be emphasized that the adolescents were reluctant to speak about the norms and rules and what was important to them. Despite the fact that the adolescents participating in the study were of different ages (14-17), the results of the analysis of the similarities between the groups showed their similarity (the test of two independent groups was used for the consistency of their Kolmogorov-Smirnov distribution, the lambda statistic was 1.19 and the critical value for alpha $=0.05$ was 1.36 ; therefore, the statistic obtained was less than the critical value, so there was no reason to reject the zero hypothesis assuming the similar distribution of results in both groups).

Table 2. How are the rules of functioning in the facility shaped? What are the main rules for the adolescents in your centre? Source: author's own work

\begin{tabular}{|l|l|l|}
\hline Categories & No of answers & Answers \\
\hline $\begin{array}{l}\text { What do the boys' attitudes } \\
\text { to the rules depend on? }\end{array}$ & $30(94 \%)$ & $\begin{array}{l}\text { - whether the boy came from his home or from another centre } \\
- \text { length of his stay matters }\end{array}$ \\
\hline $\begin{array}{l}\text { What is important for you in } \\
\text { the centre? }\end{array}$ & $30(94 \%)$ & No answer \\
\hline $\begin{array}{l}\text { What do the rules depend } \\
\text { on? }\end{array}$ & $30(94 \%)$ & - on the length of stay in the centre \\
\hline Are the rules needed? & $32(100 \%)$ & Yes \\
\hline What are the rules for? & $24(74 \%)$ & A sense of bonds, community \\
\hline $\begin{array}{l}\text { What rules are in force in } \\
\text { the centre? }\end{array}$ & $28(88 \%)$ & Informing group mates about planned escape \\
\hline Informing & $32(100 \%)$ & It is forbidden to eat food in the toilet and in the showers \\
\hline Order in loos & $23(72 \%)$ & The newcomer must not be rude to the others or boast \\
\hline $\begin{array}{l}\text { Distance- politeness } \\
\text { The rule of place } \\
\text { "places" }\end{array}$ & $15(47 \%)$ & $\begin{array}{l}\text { Taking seats in accordance with the hierarchy in certain } \\
\text { places }\end{array}$ \\
\hline $\begin{array}{l}\text { The sharing rule } \\
\text { "shares" }\end{array}$ & $20(63 \%)$ & $\begin{array}{l}\text { Sharing the contents of packages from home; an alternative } \\
\text { name was given: "survival system" - a way of making life in } \\
\text { the facility easier }\end{array}$ \\
\hline Ratting on others & $32(100 \%)$ & Ratting on others is unacceptable. \\
\hline
\end{tabular}


The descriptions of the rules were assigned to the categories created by the caretakers. The concordance coefficient was $>0.8$ in each case, except for the distance rule. In the case of this rule, the competent judges emphasised that the caretakers pointed to relationships on various levels: with caretakers, other adults, superiors and other adolescents, and described this behaviour as "in moderation", which excludes showing off and shortening the distance. Moreover, when describing the rules, the adolescents pointed at intragroup relations.

\section{Results and discussion}

Summary of the results obtained among the caretakers and discussion

In the interviews the caretakers give two important determinants of the adolescents' problems: inappropriate family patterns (71\%) and developmental problems related to problems arising during adolescence (29\%). Such attribution of adolescent behaviour removes from them a sense of guilt and responsibility for their stay in a total institution.

When answering the question: What are the reasons for the adolescents' behaviour? the caretakers pay special attention to the importance of their family home. It is where they gain bad experiences, which turns into unacceptable behaviour duplicated in the centre. The caretakers point to family failure as one of the main sources of maladjustment among the adolescents staying in the centre. The caretakers pay attention to the fact that numerous developmental needs of the adolescents have not been met, mainly emotional needs but also material ones. This perception of the causes of their behaviour would be consistent with Alina Basak who claims that "the child's behaviour depends on the needs he/she has, how he/she has learnt to satisfy them, and how the child has got used to reacting to difficulties and obstacles in the fulfilment of his/her desires" ( Basak, 2011, pp. 101109).

The caretakers also emphasise individual problems of the adolescents. This perspective helps to work on specific developmental skills. The caretakers are aware that the adolescent's family is often the main reason for his/her maladjustment, and they also notice difficult contact and the parents' unwillingness to cooperate with the institution. The legal guardians of the teenagers do not work with the institution and do not focus on youth deficits, but try to develop specific behaviour here and now. This perception of problems would be consistent with the view of Małgorzata Dubis, who claims that young people, often lost in the culture of pleasure, are faced with proposals for new ways of formulating rules of conduct, hierarchy rules and life goals choices (Dubis, 2014).

Responses related to the perception of the adolescents' reactions to the rules in the centre indicate three sources: individual (it depends on adaptation, 28\%), social (it depends on the peer group, 28\%) and situational (they obey the rules, 44\%). The indicated aspects are consistent with the methods of adaptation in a new or difficult situation described in the literature (Buchnat, 2013; Korczak, 2015;).

The method of adaptation is also related to specific deficits of the adolescents. The caretakers list five important developmental needs. These are the needs of security, being important, successful, belonging and physical activity.

Except for the need for physical activity, the above mentioned needs are widely described in the literature: the need for safety (Maciaszkowa, 1980; Pilch, Leparczyk, 2003), love, kindness and warmth (Jackowska 1980), affiliation (Domagała-Zyśk, 2012), the need to be appreciated, to maintain and increase self-esteem (Goethals, Darley, 1987).

As for the process of creating rules, the caretakers notice that the adolescents are reluctant to share knowledge about them. This is consistent with the research and educational difficulty in this aspect quoted in the literature (Granosik et al., 2014). The caretakers also highlight the change in the "source" of the rules. Once they came from the prison subculture, now they are a picture of unsatisfied needs and bad experiences from the family home. It is worth emphasizing that the caretakers agree on the sources of shaping the rules in the facility. They rarely see them as received passively from caretakers (14\%) or as a reaction to the rules of adults (rebellion, $14 \%$ ), but more often as being worked out in a group (they are shaped by adolescents themselves, $71 \%$ ).

The caretakers notice that the rules created in contrast to those in the family home are to satisfy the basic mental and material needs of the adolescents, but most importantly, they are based on generally applicable social norms. Thus, the caretakers highlight that the rules are the effect of the functioning of the group and they are also bond-forming and unifying. It can be concluded that the interaction with the "other person" is a factor contributing to the development of a teenager, which was indicated in psychology by, for example, Anna Izabela Brzezińska (2000).

The rules indicated by the caretakers refer to intragroup relations ("shares", informing, distance), hierarchy ("places"), relations with caretakers (distance) and functioning in specific places ("loos").

The caretakers agree that the length of stay in the facility is important for the hierarchy among the adolescents, but it is not the only factor that determines the position in the group. The fact that an adolescent has already stayed in other institutions also matters. The knowledge of the existence of rules and what they are like, gives the caretakers the opportunity to modify them so that they are as close as possible to the applicable social 
norms and principles. As for escapes, the caretakers notice that the escapes have a negative effect on the atmosphere in the group. The runaway is perceived as a person who breaks the common rules and should be punished after return. The ban on eating meals in toilets is also something obvious for the caretakers and thus facilitates work with young people, because it is the rule followed by everyone. The attitude of the pupils to the "new" ones, in the opinion of the caretakers, is neutral. It only matters to the group leaders. When it comes to adaptation, the caretakers say that a teenager who has previously stayed in an institution for minors often adapts faster. The importance of the so-called "place" is insignificant. As for the sharing principle, the caretakers give two reasons for this behaviour. Firstly, it is an opportunity to become accepted by the group, secondly, it is an element of becoming its permanent member. As for the rules followed by the group, all the respondents consider reporting on others blameworthy. In practice, however, the caretakers say that the adolescents often report on those who cause problems. This may be due to the fact that they do not know how to influence a groupmate in a way that does not violate the rules of the centre and they seek help from adults.

Moreover, it should be noted that although the adolescents break the rules imposed by the centre and the peers, those existing between the peers are more important and the effects of breaking them are more noticeable. Although the peer rules are often modified, they are part of the institution's culture. Thanks to the rules developed among the adolescents, their rehabilitation is facilitated. Each "new" adolescent tries to introduce the rules of conduct learned from home, and often it involves physical and verbal aggression. Confrontation with the rules among the adolescents in the centre effectively inhibits such behaviour. Obviously, in their opinion, the interventions of the caretakers are necessary, as are the rules imposed by the facility. In this aspect, the understanding of one's role is highly consistent with the results of the research presented in the meta-analysis by Mariusz Granosik, Anita Gulczyńska and Renata Szczepanik (2014). This consistency may indicate the diligence of the research carried out and thus its confirmatory nature.

Summary of the results obtained among the adolescents and discussion

Despite the difficulties in obtaining answers, it should be pointed out that all adolescents unanimously claim rules are necessary. When it comes to hierarchy, almost everyone believes that it depends on the length of stay in the facility. The longer the stay, the more rights the teenager has and the higher position in the group he should have. Over $70 \%$ believe that the "newcomers" have to earn a place in the group. It is also essential where the teenager comes from. If he has already been to other centres, the other boys will judge him through the prism of opinions about him from previous institutions. This newcomer may pose a threat to group leaders, hence their greater interest in him, up to $94 \%$. Among the respondents, less than a half believe in the so-called place rule. In the past, leaders used to occupy the "best" seats, e.g. in the canteen, and thus the seats next to them were very desirable because they determined the status in the group. The adolescents unanimously say that eating food in toilets or showers is unacceptable. It happens that some teenagers, having food products that they do not want to share, eat them in isolation, but never in toilets or showers. More than half of the respondents consider sharing to be an obligation. Most believe that other boys and caretakers should be informed about any plans to escape. They think that if they fail to prevent such an escape, they will lose in the eyes of their caretakers. Escapees are usually punished by the group.

An interesting fact is the lack of acceptance towards ratting i.e. informing the caretakers about the life of the group. This rule can largely explain the low number of answers to this question from the adolescents. When filling in the questionnaire, the respondents frequently asked additional questions. They answered it only after the interviewer clarified that the question was about something obvious. They also gave reading and writing problems as the reason for not responding.

In line with Chomczyński (2015), who described the behaviour of adolescents among juvenile detainees in terms of the habitus, the concept developed by Pierre Bourdieu (2007), the observed strategy of avoiding answers can be considered as a manifestation of an "institutional habitus" (Marciniak, 2012). According to the definition of this category, their behaviour may indicate the acquisition of high-level competences and skills in hiding their lives. In addition, it should be noted that when describing the rules, the youth emphasised intragroup relations and claimed that being rude to others or boasting was unacceptable. These rules are in line with the socially expected ones. Therefore, it can be assumed that during their rehabilitation in the facility, in some way they assimilate certain behaviour.

Discussion on the results obtained in both groups

An important element of the rules functioning in the centre is the fact that both adolescents and their caretakers notice the existence of the rules. This may indicate a certain openness in the relations between the caretakers and the adolescents, or the model of importing the creation of norms. It shows there is a common "habitus" that helps to recognize simple social situations. However, as Chomczyński (2015) says, in the process of rehabilitation, the focus should be on working on the development of individual identity and sensitizing young people to social signals hidden in the feedback. The author points out that the stay in the centre is to prepare the young person for living in an open, not closed group, in which information is hidden in contexts and it is more subtle and less clear (Chomczyński, 2015). In the light of the obtained results, it seems that the employees and management of 
educational institutions also need this sensitization to the continuous deconstruction of the "institutional habitus". This aspect is also emphasized by Anetta Jaworska (2009) and Magdalena Staniaszek (2018), who describe the work focused on preparing adolescents for social reintegration as the purpose of their stay at the youth centres.

The adolescents only briefly described the rules, while the caretakers tried to specify and name them. Moreover, it seems that the adolescents are not just passive observers, and take part in creating them. It appears that caretakers know and has access to the adolescents' life.

\section{Conclusion}

The conducted study could not fully answer the research question. On the one hand, one can notice a similar perception of the norms and rules in the centre among the caretakers and adolescents, and this answers the first part of the research question (What rules are in the centre?). However, the caretakers gave much more extensive reasons, relationships and elements related to shaping the rules in the facility than the young people. The youth unanimously indicated only two important elements: the length of stay and the experience or lack of stay in other educational institutions. Focusing on situational factors and avoiding individual determinants of behaviour in a group may have a protective function and indicate strong group processes (Bokszański, 1989; Korczak, 2015; Oleszkowicz, 2006; Wilczyńska, 2013, p. 17) ). The caretakers note that an important factor in the rehabilitation of adolescents is primarily the change of the environment (being placed in the facility), and the relationship with peers.

The observed functioning of the adolescents and the construction of norms are consistent with those described in the literature on importation approach. In this case, it may be the result of the interactions and cooperation between the adolescents and caretakers. The observed phenomenon may be a field for further extensive research and undoubtedly should become the subject of reflection of those working in the centres and students who intend to work there. The results of the research suggest that in the perspective of the importation model, the previous implicit and explicit social knowledge of both the adolescents and caretakers is of great importance. Therefore, caretakers must be especially careful because they should know the processes taking place in social rehabilitation institutions, but on the other hand, their role is to be constantly mindful and be able to separate themselves from the adolescents, their experiences and expectations. This skill seems to be crucial for modern caretakers (Heine, 2019).

Finally, it should be mentioned that the research results may also contribute to the recognition of the usefulness of the methodological research approach based on the description of phenomena in the "micro" scale and in the perspective of "interactions of respondents and researchers" (action research). The fragment of the reality, recreated in the research, allowed for methodological triangulation, creating the possibility of a more comprehensive description of the processes taking place in it.

\section{References}

Basak A. M., (2011). Zaspokajanie potrzeb i socjalizacja dziecka w rodzinie, Pedagogika Rodziny, 1(3/4), 101109

Bokszański, Z., (1989). Tożsamość, interakcja, grupa. Tożsamość jednostki w perspektywie teorii socjologicznej. Łódź: Wyd. Uniwersytetu Łódzkiego

Bourdieu, P., (2007). Szkic teorii praktyki poprzedzony trzema studiami na temat etnologii Kabylów. Kęty: Antyk

Brzezińska A.I., (2000). Społeczna psychologia rozwoju, Warszawa: Wydawnictwo SCHOLAR

Buchnat M., (2013). Przystosowanie szkolne dzieci sześcioletnich ze specjalnymi potrzebami edukacyjnymi. Leszno: Wydawnictwo Wyższej Szkoły Humanistycznej

Cicchetti, D., Rogosch, F. A., (1996), Equifinality and multifinality in developmental psychopathology. Development and Psychopathology, 8, 597-600

Ciosek M., Pastwa-Wojciechowska B., (2001). Psychologia sqdowa i penitencjarna, Warszawa: PWN

Chomczyński P., (2015). Problem etykietowania i stygmatyzacji wśród wychowanków zakładów poprawczych i schronisk dla nieletnich. Socjologiczna analiza zjawiska. Studia Socjologiczne, 4 (219), 205-236. [Online] Available: https://depot.ceon.pl/handle/123456789/8257 (February 14, 2021)

Dobijański M., (2019). Przygotowanie wychowanków Młodzieżowego Ośrodka Wychowawczego w Jaworku do aktywności na rynku pracy. Annales Universitatis Mariae Curie-Skłodowska, sectio J-PaedagogiaPsychologia, 32(4), 307-321

Dolata T., (2011). Prewencja w systemie probacji. Problemy związane z tzw. drugim życiem w niektórych polskich zakładach karnych. Probacja, 3., 58-62

Domagała-Zyśk E., (2012). Uczeń ze specjalnymi potrzebami edukacyjnymi w środowisku rówieśniczym. Lublin: Wydawnictwo KUL

Drwal R.Ł., (1981). Osobowość wychowanków zakładów poprawczych. Badania nad funkcjami podkultury zakładowej, Monografie Psychologiczne, t. 32, Wrocław: Zakład Narodowy im. Ossolińskich 
Dubis M., (2014). Wartości i style życia młodziėzy. Jagiellońskie Studia Socjologiczne, 1 , 30-38

Farnicka, M., (2019), Między pozytywizmem a interpretatywizmem - badania $w$ działaniu jako element modelu badań w psychologii, Czasopismo Psychologiczne, 25(2), 143-149

Ferguson G. A., Takane Y., (2004). Analiza statystyczna w psychologii i pedagogice, Warszawa: Państwowe Wydawnictwo Naukowe

Goethals G., Darley J. M., (1987). Social Comparison Theory:Self - Evaluation and Group Life. W: B. Mullen, G. Goethals (eds..). Theories of Group Behavior (pp.21-32). New York: Springer- Verlag

Goffman E.,(1975). Charakterystyka instytucji totalnych, W: W. Dereczyński, A. Jasińska - Kania, J. Szacki (red.). Elementy teorii socjologicznych. Materiały do dziejów współczesnej socjologii zachodniej (p. 150159). Warszawa: PWN

Goffman E., (1981). Człowieka w teatrze życia codziennego, Warszawa:PWN

Gorbaniuk O., (2016). Wykorzystywanie procedury sędziów kompetentnych w naukach społecznych i możliwości jej oceny psychometrycznej za pomoca narzędzi dostepnych $w$ statistica s. 1- 20. [Online] Available: https://media.statsoft.pl/pdf/czytelnia/wykorzystywanie_procedury_sedziow_kompetentnych.pdf, (April 20, 2020)

Granosik M., Gulczyńska A., Szczepanik R., (2014). Klimat społeczny instytucji wychowawczych $i$ jego uwarunkowania. Perspektywa pracowników $i$ wychowanków młodzieżowych ośrodków wychowawczych $(M O W)$ i socjoterapii (MOS). Łódź: Wydawnictwo Uniwersytetu Łódzkiego

Heine M., (2019). Instytucjonalna współpraca jako czynnik determinujący efektywność funkcjonowania zawodowego kuratora sądowego, Resocjalizacja Polska, 17, 37-42

Jackowska E., (1980). Środowisko rodzinne a przystosowanie społeczne dziecka w młodszym wieku szkolnym. Warszawa: Wydawnictwa Szkolne i Pedagogiczne

Jaworska A., (2009). Resocjalizacja, zagadnienia prawne, społeczne i metodyczne, Kraków: Wydawnictwo IMPULS

Korczak J., (2015). Charakterystyka indywidualnych modeli adaptacji jednostek do zmiennych warunków realizacji celów społecznych. Transdyscyplinarne Studia o Kulturze (i) Edukacji, 10, 20-39

Krause, A., Przybyliński S., (2012), Więzienie w obliczu 'drugiego życia' - podkulturowa kreacja ludzkich poczynań. w: A. Krause, S. Przybyliński (red.): Resocjalizacja penitencjarna - aktualne wyzwania $i$ rozwiązania (t.8, 117-127). Kraków: Impuls

Krukowski A., (1984). Socjologia zakładu karnego, W: B. Hołyst (red.), Problemy współczesnej penitencjarystyki $w$ świecie (43-55). Warszawa: Wydawnictwa Prawnicze

Maciaszkowa J., (1980). O współżyciu w rodzinie. Warszawa: Nasza Księgarnia

Malorny I., (2008). Lokalna sieć wsparcia i profilaktyka wobec zjawiska niedostosowania społecznego dzieci $i$ młodzieży na przykładzie miasta Bytom, Praca doktorska przygotowana w Katedrze Pedagogiki Społecznej Uniwersytetu Śląskiego w Katowicach, Katowice:UŚ

Marciniak A., (2012). Teoria w archeologii, [w:] S. Tabaczyński, D. Marciniak., A. Cyngot, A. Zalewska (red.), Przeszłość społeczna - próba konceptualizacji (84-116). Poznań: Wydawnictwo Poznańskie

Moczydłowski P., (1998). Drugie życie w instytucji totalnej, Warszawa: Wydawnictwa Prawnicze

Najwyższa Izba Kontroli, (2018). Działalność resocjalizacyjna Młodzieżowych Ośrodków Wychowawczychinformacja o wynikach kontroli, s.61, Nr: P/17/099/LWA. [Online] Available: https://www.nik.gov.pl/kontrole/P/17/099/LWA/ (October 12, 2020)

Ostaszewski K., (2008). Czynniki ryzyka i czynniki chroniące w zachowaniach ryzykownych dzieci i młodzieży [w:] J. Mazur, I. Tabak, A. Małkowska-Szkutnik, K. Ostaszewski, H. Kołoło, A. Dzielska, A. Kowalewska, Czynniki chroniace młodzież 15- letnia przed podejmowaniem zachowań ryzykownych (18-46), Raport $\mathrm{z}$ badań HBSC 2006, IMiD, Warszawa: IMiD

Oleszkowicz A., (2006). Bunt młodzieńczy. Uwarunkowania. Formy. Skutki, Warszawa: Scholar

Pilch T., Lepalczyk I., (2003). Pedagogika społeczna, Warszawa: Wydawnictwo Akademickie ŻAK

Posłuszny Ł., (2017). Instytucje totalne dzisiaj: stan badań, krytyka, rekonfiguracje, Studia Socjologiczne, 4 (227), 121-145

Rozporządzenie MEN (2011). Rozporządzenie Ministra Edukacji Narodowej z dnia 12 maja 2011 r. w sprawie rodzajów i szczegółowych zasad działania placówek publicznych, warunków pobytu dzieci i młodzieży w tych placówkach oraz wysokości i zasad odpłatności wnoszonej przez rodziców za pobyt ich dzieci w tych placówkach. Na podstawie art. 71 ust. 1 pkt 1 ustawy z dnia 7 września 1991 r. o systemie oświaty (Dz. U. z $2004 \mathrm{r}$. $\mathrm{Nr} 256$, poz. 2572, z późn. zm.) [Online] Available: http://isap.sejm.gov.pl/isap.nsf/DocDetails.xsp?id=WDU20111090631 (October 12, 2018)

Rode D., (2010). Psychologiczne uwarunkowania przemocy w rodzinie, Katowice: Wydawnictwo Uniwersytetu Śląskiego

Sarzała D., (2013). Patologiczne zachowania więźniów w kontekście izolacji i resocjalizacji penitencjarnej, Warszawa: Wydawnictwo Aspra JR 
Skręt R., (2004). Obraz podkultury więziennej we współczesnym zakładzie penitencjarnym, Nauczyciel i Szkoła, $1-2(22-23), 143-152$

Staniaszek M., (2018). Diagnoza klimatu społecznego młodzieżowych ośrodków wychowawczych w Polsce. Studia Paedagogica Ignatiana, 21, 170-178. DOI: http://dx.doi.org/10.12775/SPI.2018.1.008

Sulls J., (1977). Social comparison processes: Theoretical and empirical perspectives. Washington DC: Hemisphere

Szafrańska K., (2016). Usamodzielnianie wychowanków Młodzieżowych Ośrodków Wychowawczych. Resocjalizacja Polska, 12, 60-68)

Szaszkiewicz M., (1997). Tajemnice grypserki, Kraków: Wydawnictwo Instytutu Ekspertyz Sądowych

Thornberry T., Lizotte A., Krohn M., Farnworth M., \& Jang S., (1994), Deliquent peers, beliefes and delinquent behavior: a longitudinal test of interactional theory, Criminology, 32, 47-83

Wilczyńska A., (2013). Uwarunkowania radzenia sobie młodzieży w sytuacjach zagrożenia wykluczeniem społecznym, Katowice: Wydawnictwo Uniwersytetu Śląskiego 